\title{
Pengaruh Keputusan Investasi, Kebijakan Dividen dan Pengungkapan Laporan Berkelanjutan terhadap Nilai Perusahaan
}

Siti Anis Aniqoh ${ }^{1}$, Harry Budiantoro ${ }^{2}$

${ }^{1}$ Program Studi Akuntansi, Ekonomi, Universitas YARSI

2Program Studi Akuntansi, Ekonomi, Universitas YARSI

\begin{tabular}{|c|c|}
\hline & Abstract \\
\hline Infor & \multirow{3}{*}{$\begin{array}{l}\text { This study aims to examine the Effect of Investment Decisions, Dividend Policy, and } \\
\text { Disclosure of Continuous Reports on Company Value. The research method used is } \\
\text { quantitative and uses secondary data, namely companies in the LQ45 Index company } \\
\text { category listed on the Indonesia Stock Exchange. The samples used were five companies } \\
\text { in } 2012-2018 \text { through a purposive sampling method. The analytical method used is } \\
\text { multiple linear regression using SPSS application version 25. The results of this study } \\
\text { indicate that simultaneously Investment Decisions, Dividend Policies, and Disclosure of } \\
\text { Sustainability Reports have a significant effect on Company Value. Furthermore, } \\
\text { partially Investment Decisions and Dividend Policies affect the Company's Value, and } \\
\text { Disclosure of Sustainability Reports does not affect and the Company's Value. }\end{array}$} \\
\hline & \\
\hline & \\
\hline
\end{tabular}

Abstrak

Penelitian ini bertujuan untuk menguji Pengaruh Keputusan Investasi, Kebijakan Dividen, dan Pengungkapan Laporan Berkelanjutan Terhadap Nilai Perusahaan. Metode penelitian yang digunakan adalah metode penelitian kuantitatif dan menggunakan data sekunder yaitu perusahaan pada kategori perusahaan Indeks LQ45 yang tercatat di Bursa Efek Indonesia. Sampel yang digunakan sebanyak 5 perusahaan dengan periode tahun 2012-2018 melalui metode purposive sampling. Metode analisis yang digunakan adalah regresi linier berganda dengan menggunakan aplikasi SPSS versi 25.0. Hasil dari penelitian ini menunjukkan secara simultan Keputusan Investasi, Kebijakan Dividen, dan Pengungkapan Laporan Bekelanjutan berpengaruh signifikan terhadap Nilai Perusahaan. Selanjutnya, secara parsial Keputusan Investasi dan Kebijakan Dividen berpengaruh positif terhadap Nilai Perusahaan dan Pengungkapan Laporan Berkelanjutan tidak berpengaruh dan terhadap Nilai Perusahaan.

\footnotetext{
¿ correspondence to: Harry Budiantoro

E-mail: budiantoro.h@gmail.com
}

\section{PENDAHULUAN}

Perkembangan dunia bisnis semakin berkembang pesat ditandai dengan munculnya perusahaan dengan sektor yang beraneka ragam. Pada era globalisasi sekarang, pasar modal memiliki peran penting dalam kegiatan ekonomi pasar. Pasar menjadi salah satu kemajuan ekonomi karena dapat menjadi sumber dan alternatif bagi perusahaan (Nursania, 2019). Pergerakan trend dalam pasar modal berfungsi untuk menentukan apakah pasar tersebut sedang naik atau sedang turun. Harga saham gabungan atau yang sering lebih dikenal dengan Indeks Harga Saham Gabungan (IHSG) merupakan indeks yang didasari atas kapitalisasi seluruh saham yang tercatat di Bursa Efek Indonesia yang mana hanya mencerminkan saham-saham yang aktif dan likuid di pasar modal (Fauziah, 2019). Dengan tidak stabilnya IHSG di Bursa Efek Indonesia saat ini, maka berpengaruh terhadap indeks saham terbaik di Indonesia yaitu Indeks LQ45. 
Perusahaan yang tergabung dalam indeks LQ45 memiliki tingkat persaingan yang tinggi, sehingga menuntut kinerja dan nilai perusahaan yang selalu prima agar unggul dalam ketatnya persaingan. Faktor-faktor yang berperan dalam pergerakan indeks LQ45, yaitu tingkat suku bunga SBI sebagai patokan (benchmark) portofolio investasi di pasar keuangan Indonesia; tingkat toleransi investor terhadap risiko dan saham-saham penggerak indeks yang merupakan saham berkapitalisasi pasar besar di Bursa Efek Indonesia. Hal ini berpengaruh terhadap meningkatnya nilai perusahaan yang saham-sahamnya terdapat di dalam Indeks LQ45.

Nilai perusahaan merupakan salah satu tolak ukur kinerja perusahaan yang melibatkan elemen harga saham. Nilai perusahaan dapat diukur menggunakan dengan rasio Price to book V alue (PBV). Keunggulan PBV menggambarkan seberapa besar pasar menghargai suatu perusahaan dibandingkan kekayaan bersihnya (Febriawan \& Santosa, 2018). Terdapat beberapa faktor ekternal dan internal yang mempengaruhi nilai perusahaan. Faktor eksternal yang mempengaruhi nilai perusahaan adalah inflasi dan suku bunga. Sedangkan, faktor internal yang mempengaruhi nilai perusahaan yaitu profitabilitas, leverage, struktur modal, keputusan pendanaan, keputusan investasi, kebijakan dividen, Corporate Social Responsibility (CSR), dan Good Corporate Governance (GCG) (Nursania, 2019).

Kekayaan pemegang saham dan perusahaan dipresentasikan oleh harga pasar dari saham yang merupakan cerminan dari keputusan investasi. Perusahaan melakukan investasi bertujuan untuk mendapatkan keuntungan di masa mendatang. Pada awal Januari 2020 di Jawa Timur, telah terjadi kasus investasi bodong beromzet Rp 750 miliar yang dilakukan PT Kam and Kam. Dengan begitu, pemerintah dapat dengan sigap memberikan warning kepada para investor untuk berhati-hati terhadap model investasi yang tidak memiliki izin. Penipuan investasi bodong dianggapnya sering terjadi lantaran diperparah dengan minimnya literasi masyarakat tentang investasi (Liputan6.com).

Hal ini menjadi pusat perhatian bagi para investor untuk mengetahui pengetahuan tentang keputusan investasi. Semakin besar investasi yang ditanam, maka risiko akan semakin tinggi. Keputusan investasi merupakan faktor penting dalam fungsi keuangan, karena untuk mencapai tujuan perusahaan yaitu memaksimumkan kemakmuran pemegang saham yang dihasilkan melalui kegiatan investasi perusahaan dengan mengukur keputusan investasi menggunakan rasio Price to Earning Ratio (PER). Saham-saham dengan PER rendah lebih menarik karena laba per saham yang relatif tinggi dibandingkan dengan harga sahamnya, dengan demikian tingkat return-nya lebih baik.

Dengan meningkatnya Indeks Harga Saham pada perusahaan yang termasuk dalam indeks LQ45 sangat menarik perhatian bagi para investor untuk menanamkan modalnya guna untuk memperoleh keuntungan dalam bentuk dividen sesuai dengan harapan para investor. Apabila dividen yang dibayarkan tinggi dianggap perusahaan mempunyai prospek tingkat keuntungan yang baik dan sebaliknya. Salah satu perusahaan yang membagikan dividennya adalah Grup Astra. Pada tahun 2019, Grup Astra dapat membagikan dividen kepada pemegang saham sebesar Rp8,66 triliun atau setara dengan $40 \%$ dari laba bersih. Namun, disisi lain banyak perusahaan besar yang termasuk dalam indeks LQ45 yang tidak membagikan dividennya, tetapi disisihkan sebagai laba ditahan (SINDOnews). Kebijakan dividen diukur menggunakan rasio Dividend Payout Ratio (DPR). Dividend payout ratio adalah presentase laba yang dibagikan kepada para pemegang saham dalam bentuk dividen dari total laba yang tersedia bagi pemegang saham sesuai dengan RUPS.

Perusahaan yang terdaftar dalam indeks LQ45 sangat memperhatikan bentuk tanggung jawabnya terhadap lingkungan dan sosial untuk going concern perusahaan. Melihat kondisi beberapa tahun belakangan ini, lingkungan mengalami banyak kerusakan yang merugikan. Untuk itu, dibutuhkan kesadaran dari berbagai pihak untuk melakukan perubahan sebagai bentuk pertanggungjawaban. Mulai tahun 2017, pemerintah melalui OJK mengeluarkan sebuah peraturan terbaru yaitu Nomor 51/POJK.03/2017 tentang kewajiban pembuatan laporan keberlanjutan (sustainability report) bagi LJK, 
Emiten, dan Perusahaan Publik yang nantinya mendampingi laporan tahunan (annual report). Namun, pada prosesnya peraturan tersebut belum sepenuhnya dilaksanakan. Hal ini tentu menjadi salah satu yang diperhatikan investor, sehingga dengan semakin baik tingkat pelaksanaan dan pengungkapan laporan berkelanjutan perusahaan maka memperoleh kepercayaan dari investor ketika berinvestasi disebuah perusahaan, dengan kata lain akan meningkatkan nilai perusahaan.

Dalam penelitian ini laporan berkelanjutan difokuskan pada Corporate Social Responsibility (CSR) yang diukur menggunakan Corporate Social Responsibility Disclosure Index (CSRDI). CSRDI adalah suatu pengukuran untuk mengukur sejauh mana perusahaan bertanggung jawab terhadap sosial, lingkungan, etika, hak asasi manusia dan keprihatinan konsumen dalam operasi bisnis mereka dan strategi inti, dalam kerjasama erat dengan para pemangku kepentingan. Investor cenderung lebih memilih perusahaan-perusahaan yang memiliki track record yang baik di pasar modal, salah satunya adalah perusahaan-perusahaan yang termasuk dalam Indeks LQ45. Berdasarkan latar belakang di atas keputusan investasi, kebijakan dividen, dan pengungkapan laporan berkelanjutan berpengaruh terhadap nilai perusahaan, dengan demikian tujuan penelitian ini

1. Untuk mengetahui keputusan investasi, kebijakan dividen, dan pengungkapan laporan berkelanjutan secara parsial berpengaruh terhadap nilai perusahaan.

2. Untuk mengetahui keputusan investasi, kebijakan dividen, dan pengungkapan laporan berkelanjutan secara simultan berpengaruh terhadap nilai perusahaan.

\section{KAJIAN TEORI}

\section{Teori Persinyalan (Signalling Theory)}

Menurut Brigham dan Houston (2011) signaling theory merupakan suatu perilaku manajemen perusahaan dalam memberi petunjuk untuk investor terkait pandangan manajemen pada prospek perusahaan untuk masa mendatang. Nilai perusahaan yang baik dapat menjadi sinyal bagi para investor untuk membuat keputusan investasi, dengan begitu investor tertarik dalam berinvestasi dengan membeli saham, akibatnya saham perusahaan naik. Saham perusahaan meningkat nilai perusahaan juga meningkat.

\section{Nilai Perusahaan}

Nilai perusahaan menurut (Santosa, 2019) adalah kinerja perusahaan yang dicerminkan oleh harga saham yang dibentuk oleh permintaan dan penawaran pasar modal yang merefleksikan penilaian masyarakat terhadap kinerja perusahaan.

\section{Keputusan Investasi}

Keputusan investasi menurut Brigham dan Houston (2016) adalah kebijakan terpenting dari kedua kebijakan lain dalam manajemen keuangan, yaitu keputusan pendanaan dan kebijakan dividen. Investasi modal sebagai aspek utama kebijakan manajemen keuangan karena investasi adalah bentuk alokasi modal yang realisasinya harus menghasilkan manfaat atau keuntungan mendatang.

\section{Kebijakan Dividen}

Kebijakan dividen menurut Ambarwati (2010) merupakan kebijakan yang diambil manajemen perusahaan untuk memutuskan membayarkan sebagian keuntungan perusahaan kepada pemegang saham dari pada menahannya sebagai laba ditahan untuk diinvestasikan kepada pemegang saham daripada menahannya sebagai laba ditahan untuk diinvestasikan kembali agar mendapatkan capital gains.

\section{Pengungkapan Laporan Berkelanjutan}

Menurut Elkington (2004) laporan berkelanjutan atau sustainability report yaitu laporan yang memuat tidak hanya informasi kinerja keuangan tetapi juga informasi non keuangan yang terdiri dari informasi aktivitas sosial dan lingkungan yang memungkinkan perusahaan bisa bertumbuh secara berkesinambungan (sustainable performance). 


\section{Penelitian Terdahulu}

Beberapa hasil penelitian yang relevan dengan penelitian ini yaitu:

\section{Tabel 1 Penelitian Terdahulu}

\begin{tabular}{|c|c|c|c|}
\hline No. & Peneliti dan Judul & Variabel dan Metode & Hasil \\
\hline 1. & $\begin{array}{l}\text { Aridho Choirul Umam dan Uli } \\
\text { Hartono (2019) } \\
\text { Pengaruh Ukuran Perusahaan, } \\
\text { Profitabilitas, Struktur Modal, } \\
\text { Kebijakan Dividen, GCG dan } \\
\text { CSR Terhadap Nilai } \\
\text { Perusahaan (Studi pada } \\
\text { Perusahaan Sektor Finance di } \\
\text { Bursa Efek Indonesia) }\end{array}$ & $\begin{array}{ll}\text { Independen: } \\
\text { - } \quad \text { Ukuran Perusahaan } \\
\text { - } \quad \text { Profitabilitas } \\
\text { - } \quad \text { Struktur Modal } \\
\text { - } \quad \text { Kebijakan Dividen } \\
\text { - } \quad \text { Kepemilikan Manajerial } \\
\text { - } \quad \text { Kepemilikan Institusional } \\
\text { - } \quad \text { Komisaris } \\
\text { - } \quad \text { Independen } \\
\text { - } \quad \text { CSR } \\
\text { Dependen: } \\
\text { - Nilai Perusahaan } \\
\text { Metode: } \\
\text { Metode regresi linear berganda. }\end{array}$ & $\begin{array}{l}\text { 1) Ukuran } \begin{array}{r}\text { perusahaan, } \\
\text { dividen, }\end{array} \\
\text { Kebijakan } \\
\text { Kepemilikan Institusional dan } \\
\text { CSR memiliki pengaruh } \\
\text { positif terhadap nilai } \\
\text { perusahaan. } \\
\text { 2) } \begin{array}{l}\text { Profitabilitas } \\
\text { pengaruh negatif terhadap }\end{array} \\
\text { nilai perusahaan. } \\
\text { 3) Struktur modal, Kepemilikan } \\
\text { Manajerial, dan Komisaris } \\
\text { Independen tidak memiliki } \\
\text { pengaruh terhadap nilai } \\
\text { perusahaan. }\end{array}$ \\
\hline 2. & $\begin{array}{l}\text { Elvia Astri Fardiana (2018) } \\
\text { Pengaruh Kebijakan Deviden, } \\
\text { dan Struktur Modal Terhadap } \\
\text { Nilai Perusahaan pada } \\
\text { Perusahaan Food and Beverage. }\end{array}$ & $\begin{array}{l}\text { Independen: } \\
\text { - } \quad \text { Kebijakan Deviden } \\
\text { - } \quad \text { Ukuran Perusahaan } \\
\text { - } \quad \text { Struktur Modal } \\
\text { - } \quad \text { Corporate Social Responsibility } \\
\text { Dependen: } \\
\text { - Nilai Perusahaan } \\
\text { Metode: } \\
\text { Metode regresi linear berganda }\end{array}$ & $\begin{array}{l}\text { 1) Kebijakan deviden tidak } \\
\text { berpengaruh terhadap nilai } \\
\text { perusahaan. } \\
\text { 2) Ukuran perusahaan dan } \\
\text { Corporate social responsibility } \\
\text { (CSR) berpengaruh negatif } \\
\text { terhadap nilai perusahaan. } \\
\text { 3) Struktur modal berpengaruh } \\
\text { positif terhadap nilai } \\
\text { perusahaan. }\end{array}$ \\
\hline 3. & $\begin{array}{l}\text { Hida Efri Nurfina (2016) } \\
\text { Pengaruh Pengungkapan } \\
\text { Corporate Social Responsibility, } \\
\text { Kebijakan Dividen, } \\
\text { Profitabilitas, Struktur Modal, } \\
\text { dan Ukuran Perusahaan } \\
\text { terhadap Nilai Perusahaan }\end{array}$ & $\begin{array}{l}\text { Independen: } \\
\text { - } \quad \text { Pengaruh Pengungkapan } \\
\text { - Corporate Social Responsibility } \\
\text { - } \quad \text { Kebijakan Dividen } \\
\text { - } \quad \text { Profitabilitas } \\
\text { - } \quad \text { Struktur Modal } \\
\text { - } \quad \text { Ukuran Perusahaan } \\
\text { Dependen: } \\
\text { - } \quad \text { Nilai Perusahaan } \\
\text { Metode: } \\
\text { Metode regresi linear berganda }\end{array}$ & $\begin{array}{l}\text { 1) Pengungkapan Corporate Social } \\
\text { Responsibility dan Kebijakan } \\
\text { dividen tidak berpengaruh } \\
\text { terhadap nilai perusahaan. } \\
\text { 2) Profitabilitas, Ukuran } \\
\text { perusahaan berpengaruh } \\
\text { positif terhadap nilai } \\
\text { perusahaan. } \\
\text { 3) Struktur modal berpengaruh } \\
\text { negatif terhadap nilai } \\
\text { perusahaan. }\end{array}$ \\
\hline 4. & $\begin{array}{l}\text { Ayu Tiarawati (2015) } \\
\text { Pengaruh Keputusan Investasi, } \\
\text { Keputusan Pendanaan, } \\
\text { Kebijakan Deviden dan } \\
\text { Pengungkapan Corporate Social } \\
\text { Responsibility terhadap Nilai } \\
\text { Perusahaan }\end{array}$ & $\begin{array}{l}\text { Independen: } \\
\text { - } \quad \text { Keputusan Investasi } \\
\text { - } \quad \text { Keputusan Pendanaan } \\
\text { - } \quad \text { Kebijakan Deviden } \\
\text { - } \quad \text { Pengungkapan Corporate } \\
\quad \text { Social Responsibility } \\
\quad \text { Dependen: } \\
\text { - Nilai Perusahaan } \\
\text { Metode: } \\
\text { Metode regresi linear berganda }\end{array}$ & $\begin{array}{l}\text { 1) Keputusan investasi } \\
\text { Kebijakan dividen } \\
\text { berpengaruh positif terhadap } \\
\text { nilai perusahaan. } \\
\text { 2) Keputusan Pendanaan } \\
\text { berpengaruh negatif terhadap } \\
\text { nilai perusahaan. } \\
\text { 3) Pengungkapan Corporate Social } \\
\text { Responsibility tidak berpengaruh } \\
\text { terhadap nilai perusahaan. }\end{array}$ \\
\hline
\end{tabular}




\section{Kerangka Pemikiran Konseptual}

Penelitian ini berusaha mencari pengaruh variabel kebijakan dividen, dan pengungkapan laporan berkelanjutan pada perusahaan yang go public atau yang sudah terdaftar (listing) di BEI. Kerangka pemikiran dalam penelitian ini dapat digambarkan sebagai berikut (Sugiarto \& Santosa, 2018):

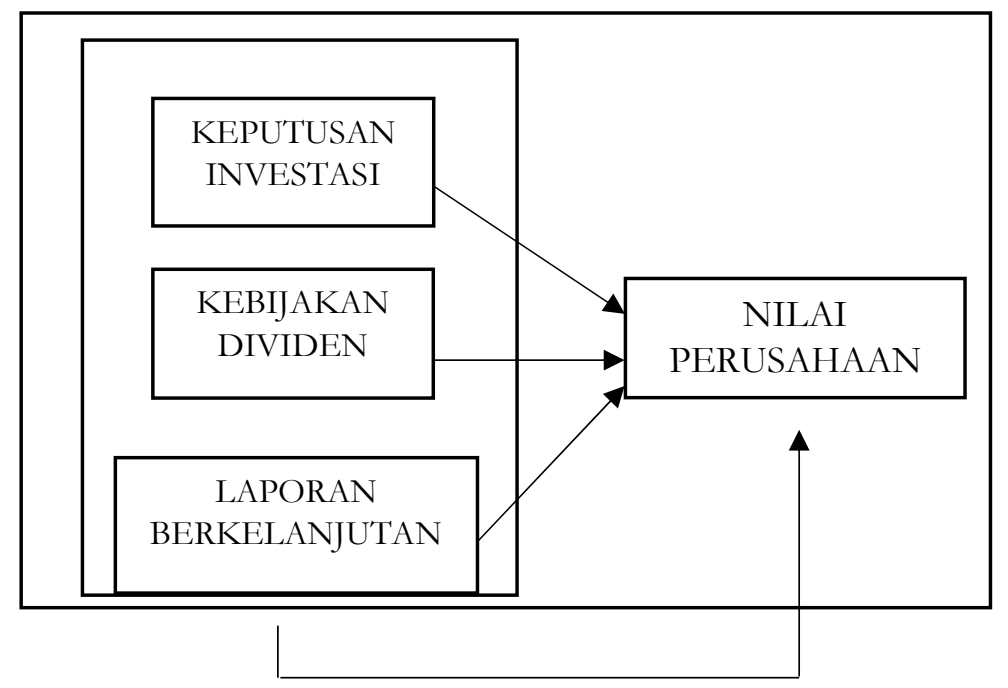

Gambar 1. Kerangka Pemikiran

\section{METODE PENELITIAN}

\section{Desain Penelitian}

Jenis penelitian yang dilakukan adalah penelitian kuantitatif. Penelitian ini terdiri dari dua variabel yaitu, variabel dependen terdiri dari keputusan investasi $\left(\mathrm{X}_{1}\right)$, kebijakan dividen $\left(\mathrm{X}_{2}\right)$, dan pengungkapan laporan berkelanjutan $\left(\mathrm{X}_{3}\right)$, serta variabel independen terdiri dari nilai perusahaan (Y).

\section{Teknik Pengambilan Data}

Populasi dalam penelitian ini adalah perusahaan yang sahamnya masuk ke dalam LQ45 yang telah tercatat di Bursa Efek Indonesia (BEI) pada tahun 2012 hingga tahun 2018. Penelitian ini menggunakan teknik sampling, yaitu teknik pengambilan sampel karena tidak semua sampel mempunyai data yang lengkap sehingga sulit untuk dilakukan pengukuran. Kriteria perusahaan yang dijadikan sampel dalam penelitian ini adalah:

Tabel 2. Prosedur Pemilihan Sampel

\begin{tabular}{lc}
\hline Kriteria & Jumlah \\
\hline $\begin{array}{lc}\text { Perusahaan LQ45 yang secara konsisten terdaftar di Bursa Efek Indonesia tahun 2012-2018 } \\
\text { Perusahaan LQ45 yang tidak membuat laporan berkelanjutan dari tahun 2012-2018 secara }\end{array}$ & 38 \\
\hline berturut-turut. & $(13)$ \\
\hline Perusahaan LQ45 yang tidak membagikan dividen dari tahun 2012-2018 secara berturut-turut. & $(20)$ \\
\hline Jumlah Perusahan Sampel & 5 \\
\hline Total Tahun Pengamatan & 7 \\
\hline Jumlah Total Sampel Pengamatan & 35 \\
\hline
\end{tabular}


Berdasarkan data yang telah ditetapkan, jumlah sampel perusahaan yang memenuhi kriteria sebanyak 5 perusahaan yang sangat diminat oleh para investor karena termasuk 45 perusahaan dengan kinerja terbaik disemua sektor indeks saham terbaik di Indonesia yaitu indeks LQ45 yang terdaftar di Bursa Efek Indonesia 2012 sampai 2018. Sampel dalam penelitian ini dapat dilihat pada Table 3. berikut ini:

Tabel 3 Sampel Penelitian

\begin{tabular}{ccl}
\hline No. & Kode Saham & \multicolumn{1}{c}{ Nama Perusahaan Tercatat } \\
\hline 1 & ASII & Astra International Tbk. \\
2 & BBCA & Bank Central Asia Tbk. \\
3 & ITMG & Indo Tambangraya Megah Tbk. \\
4 & UNTR & United Tractors Tbk. \\
5 & UNVR & Unilever Indonesia Tbk. \\
\hline \multicolumn{2}{l}{ Sumber: BEI (2018) }
\end{tabular}

\section{Operasionalisasi Variabel Penelitian dan Skala Pengukuran}

Untuk memberikan gambaran yang lebih jelas tentang variabel penelitian, maka disajikan tabel sebagai berikut:

Tabel 4 Operasionalisasi Variabel

\begin{tabular}{|c|c|c|}
\hline Konsep Variabel & Indikator & Skala Pengukuran \\
\hline $\begin{array}{l}\text { Nilai Perusahan (Y) } \\
\text { Nilai perusahaan adalah nilai jual } \\
\text { sebuah perusahaan sebagai suatu } \\
\text { bisnis yang sedang beroperasi } \\
\text { (Sartono, 2010) }\end{array}$ & PBV $=\frac{\text { Harga Saham }}{\text { Nilai Buku }}$ & Rasio \\
\hline $\begin{array}{l}\text { Keputusan investasi (X1) } \\
\text { Keputusan investasi adalah kebijakan } \\
\text { terpenting dari kedua kebijakan lain } \\
\text { dalam manajemen keuangan, yaitu } \\
\text { keputusan pendanaan dan kebijakan } \\
\text { dividen (Harmono, 2011) }\end{array}$ & $\mathrm{PER}=\frac{\text { Harga Saham }}{\text { Laba Per Saham }}$ & Rasio \\
\hline $\begin{array}{l}\text { Kebijakan Dividen (X2) } \\
\text { Kebijakan yang diambil manajemen } \\
\text { perusahaan untuk memutuskan } \\
\text { membayarkan sebagian keuntungan } \\
\text { perusahaan kepada pemegang saham } \\
\text { dari pada menahannya sebagai laba } \\
\text { ditahan untuk diinvestasikan kepada } \\
\text { pemegang saham daripada } \\
\text { menahannya sebagai laba ditahan } \\
\text { untuk diinvestasikan kembali agar } \\
\text { mendapatkan capital gains } \\
\text { (Ambarwati, 2010). }\end{array}$ & DPR $=\frac{\text { Dividen Per Saham }}{\text { Laba Per Saham }}$ & Rasio \\
\hline
\end{tabular}




\begin{tabular}{|c|c|c|}
\hline Konsep Variabel & Indikator & Skala Pengukuran \\
\hline $\begin{array}{l}\text { Pengungkapan Laporan } \\
\text { Berkelanjutan (Y) } \\
\text { Laporan berkelanjutan adalah } \\
\text { laporan yang memuat tidak saja } \\
\text { informasi kinerja keuangan tetapi } \\
\text { juga informasi non keuangan yang } \\
\text { terdiri dari informasi aktivitas sosial } \\
\text { dan lingkungan yang memungkinkan } \\
\text { perusahaan bisa bertumbuh secara } \\
\text { berkesinambungan (Elkington, } \\
\text { 2004). }\end{array}$ & \begin{tabular}{l}
$\qquad$ CSRDI $=\frac{\sum \mathrm{Xj}}{\mathrm{Nj}}$ \\
Keterangan : \\
CSRDI $\mathrm{j}:$ corporate social \\
responsibility disclosure index \\
perusahaan $\mathrm{j}$ \\
$\mathrm{Xj}:$ jumlah item yang \\
diungkapkan oleh perusahaan $\mathrm{j}$ \\
$\mathrm{Nj}:$ jumlah item \\
pengungkapan CSR \\
\multicolumn{4}{c}{ (Untung, 2014) }
\end{tabular} & Nominal \\
\hline
\end{tabular}

\section{Teknik Analisis Data}

Dalam penelitian ini, teknik pengumpulan data yang digunakan adalah teknik dokumentasi. Teknik ini dilakukan dengan mengumpulkan dan memanfaatkan data laporan keuangan auditan, laporan tahunan, dan laporan berkelanjutan perusahaan indeks LQ45 selama periode tahun 2012-2018 yang diperoleh dari Bursa Efek Indonesia. Teknik analisis data yang digunakan dalam penelitian ini adalah metode analisis data kuantitatif. Alat analisis data yang digunakan adalah SPSS versi 25.0 SPSS.

\section{HASIL DAN PEMBAHASAN}

\section{Deskriptif Data}

Statistik deskriptif memberi gambaran umum mengenai variabel- variabel dalam penelitian ini. Data statistik deskriptif yang disertakan adalah 5 perusahaan indeks LQ45 yang terdaftar di BEI pada tahun 2012-2018. Berdasarkan hasil deskriptif statistik pada Tabel 5 akan ditampilkan karakteristik sampel yang digunakan di dalam penelitian ini meliputi: jumlah sampel $(\mathrm{N})$, rata- rata sampel (mean), nilai maksimum, nilai minimum serta standar deviasi untuk masing- masing variabel. Dapat dilihat pada tabel berikut:

Tabel 5 Hasil Analisis Deskriptif Data

\begin{tabular}{|c|c|c|c|c|c|}
\hline \multicolumn{6}{|c|}{ Descriptive Statistios } \\
\hline & $\mathrm{H}$ & Нгиนแา & M⿻amin & Nean & Slut Derasaor \\
\hline IEF (XT) & as & $\$ .32$ & 5..63 & 20.2811 & 13.9832 \\
\hline DOR C $-2:$ & 35 & $0 \mathrm{~B}$ & 13 & 1811 & 20070 \\
\hline SGRD $(\times 3)$ & 35 & 11 & 71 & 2809 & $\because 1205$ \\
\hline PFYM & 35 & 58 & $3 \geqslant 44$ & 1.000 .3 & 7.9 segn? \\
\hline WalizH Cisewises & 35 & & & & \\
\hline
\end{tabular}

Sumber: Hasil olahan Peneliti dengan SPSS 25.0

\section{Hasil Pengujian Asumsi Klasik}

\section{Uji Normalitas}

Menurut Santosa dan Hidayat (2014) uji normalitas bertujuan untuk menguji apakah dalam model regeresi, variabel pengganggu atau residual memiliki distribusi normal. Uji normalitas residual dengan metode grafik yaitu dengan melihat penyebaran data pada sumber diagonal pada grafik Normal 
PP Plot of regression standardized residual dan grafik histogram. Berikut Gambar 2. mengenai grafik normal Probability Plot (P-Plot):

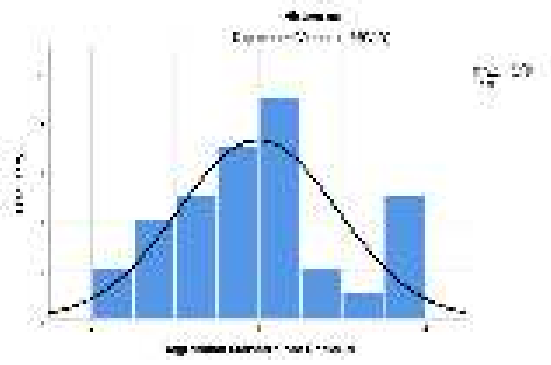

Sumber: Hasil olahan Peneliti

Gambar 2 Grafik Histogram Keputusan Investasi, Kebijakan Dividen, dan Pengungkapan Laporan Berkelanjutan terhadap Nilai Perusahaan

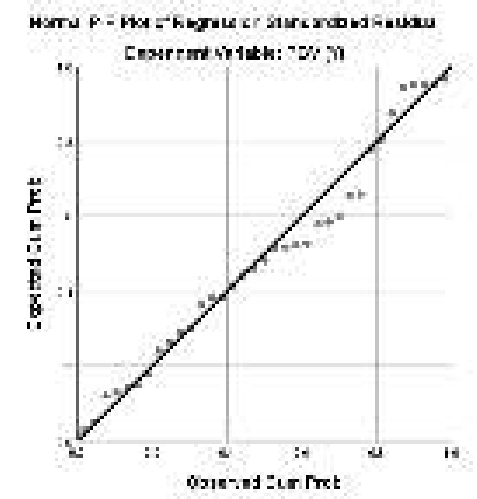

Sumber: Hasil olahan Peneliti

Gambar 3 Grafik Normal P-Plot Keputusan Investasi, Kebijakan Dividen, dan Pengungkapan Laporan Berkelanjutan terhadap Nilai Perusahaan

Berdasarkan hasil uji normalitas dengan melihat tampilan grafik histogram maupun grafik normal P- Plot dapat disimpulkan bahwa grafik histogram mengikuti arah garis diagonal atau grafik histogramnya menunjukkan pola distribusi normal dan pada grafik normal P- Plot terlihat titik- titik menyebar di sekitar garis diagonal. Yang berarti kedua grafik ini menunjukkan bahwa model regresi memenuhi asumsi normalitas.

Tabel 6 Hasil Analisis Uji Statistik non-parametrik Kolmogrov-Smirnov (K-S)

One-Sample Kolmogorov-Smirnov Test

\begin{tabular}{|c|c|c|}
\hline & & $\begin{array}{l}\text { Unstandardiz } \\
\text { ed Residual }\end{array}$ \\
\hline N & & 35 \\
\hline \multirow[t]{2}{*}{ Normal Parameters ${ }^{a \cdot b}$} & Mean & .0000000 \\
\hline & Std. Deviation & 7.56106682 \\
\hline \multirow[t]{3}{*}{ Most Extreme Differences } & Absolute & .111 \\
\hline & Positive & .111 \\
\hline & Negative & -.092 \\
\hline Test Statistic & & .111 \\
\hline Asymp. Sig. (2-tailed) & & $.200^{c . d}$ \\
\hline \multicolumn{3}{|c|}{ a. Test distribution is Normal. } \\
\hline \multicolumn{3}{|c|}{ b. Calculated from data. } \\
\hline \multicolumn{3}{|c|}{ c. Lilliefors Significance Correction. } \\
\hline
\end{tabular}

Sumber: Hasil olahan 
Besarnya nilai Test Statistik Kolmogorov-Smirnov adalah 0,111 dan signifikan pada 0,200 yaitu diatas 0,05. Hal ini berarti HA ditolak yang berarti data residual terdistribusi normal dan hasilnya konsisten dengan uji sebelumnya.

\section{Uji Multikolonieritas}

Menurut Ghozali (2018) ini bertujuan untuk menguji apakah pada model regresi ditemukan adanya korelasi antar variabel independen. Hasil uji multikolonieritas dapat dilihat pada Tabel 6 berikut ini:

\section{Tabel 7 Hasil Analisis Statistik Multikolonieritas}

\begin{tabular}{|c|c|c|c|c|c|c|c|c|}
\hline \multicolumn{9}{|c|}{ Coefficlents" } \\
\hline \multirow[b]{2}{*}{ wasai } & & \multicolumn{2}{|c|}{ Unetandansad Caencierts } & \multirow{2}{*}{$\begin{array}{c}\text { Btandarissed } \\
\text { Coefsciorts } \\
\text { Beta }\end{array}$} & \multirow[b]{2}{*}{1} & \multirow[b]{2}{*}{$8 \mathrm{ia}$} & \multicolumn{2}{|c|}{ Colmesuti Statstes } \\
\hline & & E & Strit Emor & & & & Tolemente & w \\
\hline \multirow[t]{4}{*}{1} & Fontarts & -29.760 & 4053 & & -7.100 & 000 & & \\
\hline & PEF $(x)$ & 1549 & 107 & $B 63$ & 14.489 & DOD & B29: & 1.021 \\
\hline & CPR $Q 9$ & 16.045 & 4.703 & 209 & 3,412 & 002 & .876 & 1.143 \\
\hline & CSRDiOOI & 10.969 & 12418 & 052 & 984 & 34 & 939 & 1.008 \\
\hline
\end{tabular}

Sumber: Hasil olahan Peneliti dengan SPSS 25.0

Hasil analisis menunjukkan bahwa nilai Tolerance menunjukkan tidak ada variabel Independen yang memiliki nilai Tolerance kurang dari 0,10 yang berarti tidak ada korelasi antar variabel independen yang nilainya lebih dari $95 \%$. Hasil perhitungan nilai Variance Inflation Factor (VIF) juga menunjukkan hal yang sama tidak ada satu variabel independen yang memiliki nilai VIF lebih dari 10. Jadi dapat disimpulkan bahwa tidak ada multikolonieritas antar variabel independen dalam model regeresi.

\section{Uji Heteroskedastisitas}

Menurut Santosa dan Hidayat (2014), pengujian heteroskedastisitas bertujuan untuk menentukan apakah dalam model regresi terjadi ketidaksamaan varian dari residual satu pengamatan ke pengamatan yang lain. Model regresi yang baik adalah yang Homoskesdatisitas atau tidak terjadi Heteroskedastisitas. Hasil tersebut dapat dilihat pada Gambar 4 sebagai berikut :

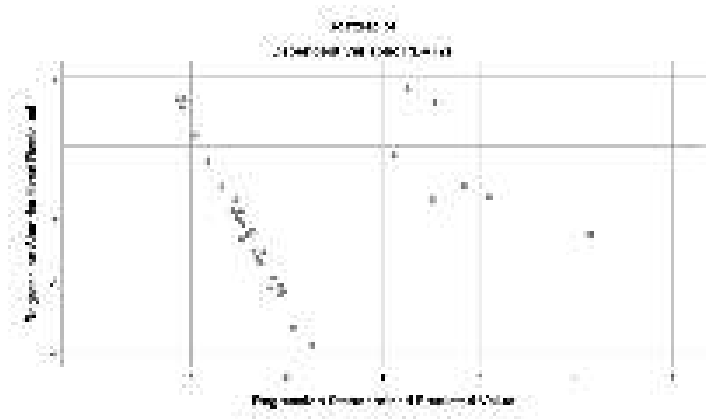

Sumber: Hasil olahan Peneliti dengan SPSS 25.0

\section{Gambar 4 Hasil Uji Heteroskedastisitas - Grafik Scatterplot}

Dari grafik Scatterplot terlihat titik- titik menyebar secara acak tersebar baik di atas maupun di bawah angka nol pada sumbu Y. Hal ini dapat disimpulkan bahwa tidak terjadi heteroskedastisitas pada model regresi, sehingga model regresi layak dipakai untuk memprediksi pengaruh keputusan investasi, 
kebijakan dividen, dan pengungkapan laporan berkelanjutan terhadap nilai perusahaan. Dapat dilihat pada Tabel berikut.

Hasil tampilan output SPSS 25.0 dengan jelas menunjukkan bahwa tidak ada satupun variabel independen yang signifikan secara statistik mempengaruhi variabel dependen nilai Absolut Ut (AbsUt). Hal ini terlihat dari probabilitas signifikansinya di atas tingkat kepercayaan 5\%. Jadi dapat disimpulkan model regresi tidak mengandung adanya Heteroskedastisitas.

\section{Tabel 8 Hasil Analisis Uji Glejser}

\begin{tabular}{|c|c|c|c|c|c|c|}
\hline \multicolumn{7}{|c|}{ Coefficients ${ }^{a}$} \\
\hline \multirow[b]{2}{*}{ Modei } & & \multicolumn{2}{|c|}{ Unstandardias d Coelficierts } & \multirow{2}{*}{$\begin{array}{c}\text { Stancarobed } \\
\text { Coeflizierns } \\
\text { Bata }\end{array}$} & \multirow[b]{2}{*}{7} & \multirow[b]{2}{*}{ Sig. } \\
\hline & & $B$ & 5td Erroe & & & \\
\hline \multirow[t]{4}{*}{1} & Censtaro & 4.656 & 2.530 & & 1.321 & .078 \\
\hline & PEF OX1) & -.030 & .067 & -984 &.$-<57$ & .657 \\
\hline & DPRA $2:$ & 1.351 & 2.935 & $58 ?$ & .480 & .849 \\
\hline & $C 3 \cap D,(x 3)$ & 4.354 & 7.749 & 103 & .562 & .578 \\
\hline
\end{tabular}

a. Depancent Variatle, Abst.

Sumber: Hasil olahan

\section{Uji Autokorelasi}

Menurut Ghozali (2018) uji autokorelasi bertujuan untuk menguji apakah dalam model regresi linear ada korelasi antara kesalahan pengganggu pada periode $t$ dengan kesalahan pengganggu pada periode t-1 (sebelumnya). Dapat dilihat pada tabel berikut:

\section{Tabel 9 Hasil Analisis Uji Autokorelasi}

Runs Test

\begin{tabular}{|c|c|}
\hline & $\begin{array}{l}\text { Unstandarde } \\
\text { ed Fesldual }\end{array}$ \\
\hline Test Value" & -352224 \\
\hline Cases-e TesiValue & 17 \\
\hline Cases $x=$ Test Walu= & 19 \\
\hline Totaicasas & 35 \\
\hline Number olRuns & 13 \\
\hline$z$ & .000 \\
\hline Aswnip sic (?-taled) & 1.003 \\
\hline
\end{tabular}

a. Yedia।

Sumber: Hasil olahan

Dari Tabel 9 di atas menunjukkan bahwa Asymp. Sig. (2-tailed) 1,000 yang menandakan lebih dari 0,05 yang berarti $\mathrm{H}_{0}$ diterima sehingga disimpulkan bahwa residual random (acak) atau tidak terjadi autokorelasi antar nilai residual. 


\section{Hasil Pengujian Hipotesis}

Hasil Pengujian Parsial (Uji Statistik t)

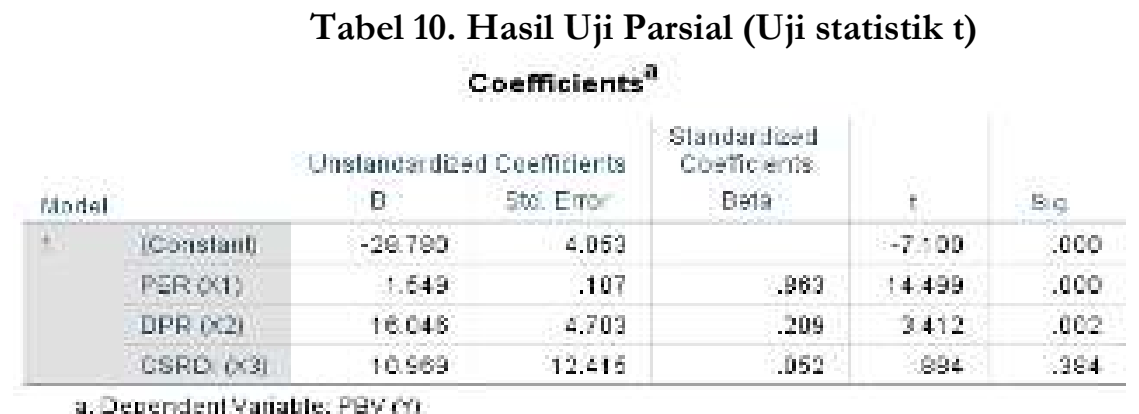

Sumber: Hasil olahan

Berdasarkan hasil uji statistik t pada Tabel 4.6 di atas, maka diperoleh persamaan regresi sebagai berikut :

$$
\mathrm{PBV}_{\mathrm{it}}=-28,780+1,549 P E R_{\mathrm{it}}+16,046 D P R_{\mathrm{it}}+10,969 C S R D I_{\mathrm{it}}
$$

Penjelasan dari persamaan regresi berganda yang terbentuk diatas diketahui bahwa konstanta sebesar -28,780 menyatakan apabila variabel independen yaitu Keputusan Investasi, Kebijakan Dividen, dan Pengungkapan Laporan Berkelanjutan dianggap konstan, maka rata- rata Nilai Perusahaan sebesar $-28,780$.

\section{Pengujian Hipotesis Hipotesis Pertama (H1)}

Berdasarkan tabel uji $\mathrm{t}$ diatas dapat dilihat bahwa Keputusan Investasi $\left(\mathrm{X}_{1}\right)$ memiliki nilai $\mathrm{t}$ hitung $>\mathrm{t}$ tabel $(14,499>2,03951)$ dengan tingkat signifikansi sebesar 0,000 maka keputusan adalah $\mathrm{Ha}_{1}$ diterima dan $\mathbf{H} \mathbf{0}_{1}$ ditolak. Artinya bahwa terdapat pengaruh positif antara Keputusan Investasi $\left(\mathrm{X}_{1}\right)$ terhadap Nilai Perusahaan $(\mathrm{Y})$. Jadi semakin tinggi nilai Keputusan Investasi mempengaruhi Nilai Perusahaan.

\section{Pengujian Hipotesis Hipotesis Kedua (H2)}

Berdasarkan tabel uji t diatas dapat dilihat bahwa Kebijakan Dividen $\left(\mathrm{X}_{2}\right)$ memiliki nilai $\mathrm{t}$ hitung $>$ t tabel $(3,412>2,03951)$ dengan tingkat signifikansi sebesar 0.002 maka keputusan adalah $\mathrm{Ha}_{2}$ diterima dan $\mathbf{H O}_{2}$ ditolak. Artinya bahwa terdapat pengaruh positif antara Kebijakan Dividen $\left(\mathrm{X}_{2}\right)$ terhadap Nilai Perusahaan $(\mathrm{Y})$. Jadi semakin tinggi Kebijakan Dividen akan semakin tinggi Nilai Perusahaan.

\section{Pengujian Hipotesis Hipotesis Ketiga (H3)}

Berdasarkan tabel uji t diatas dapat dilihat bahwa Pengungkapan Laporan Berkelanjutan $\left(\mathrm{X}_{3}\right)$ memiliki nilai $\mathrm{t}$ hitung $<\mathrm{t}$ tabel $(0,884<2,03951)$ dengan tingkat signifikansi sebesar 0,384 maka keputusan adalah terima $\mathbf{H a}_{3}$ ditolak dan $\mathbf{H o}_{3}$ diterima. Artinya bahwa tidak terdapat pengaruh antara Pengungkapan Laporan Berkelanjutan terhadap Nilai Perusahaan. Jadi tinggi atau rendahnya nilai Pengungkapan Laporan Berkelanjutan tidak akan mempengaruhi Nilai Perusahaan (PBV). 


\section{Hasil Pengujian Simultan (Uji Statistik F)}

Tabel 11 Hasil Uji Simultan (Uji Statistik F)

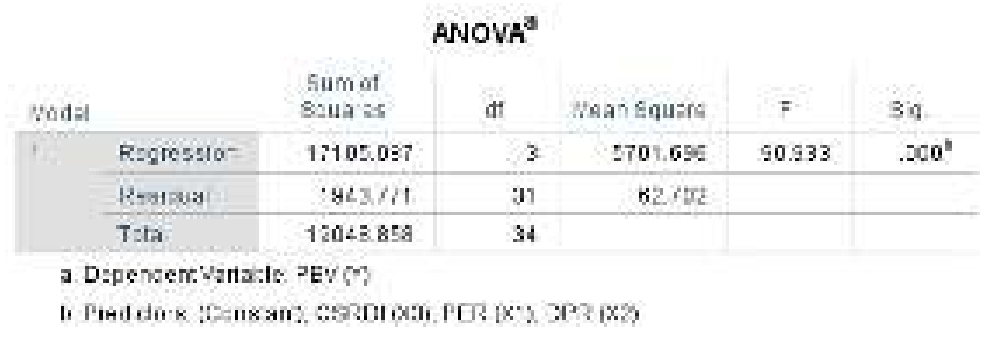

Sumber: Hasil olahan Peneliti dengan SPSS 25.0

Berdasarkan tabel ANOVA diatas dapat dilihat bahwa nilai F hitung $>$ F tabel $(90,933>2,90)$ dengan tingkat signifikansi sebesar $0.000<0.05$, oleh karena itu keputusan adalah $\mathbf{H a}$ diterima dan Ho ditolak. Sehingga, dapat disimpulkan bahwa terdapat pengaruh secara bersama-sama Keputusan Investasi $\left(\mathrm{X}_{1}\right)$, Kebijakan Dividen $\left(\mathrm{X}_{2}\right)$, dan Pengungkapan Laporan Berkelanjutan $\left(\mathrm{X}_{3}\right)$ terhadap Nilai Perusahaan $(\mathrm{Y})$.

\section{Hasil Koefisien Determinasi}

Tabel 12 Hasil Analisis Uji Koefisien Determinasi $\left(\mathbf{R}^{2}\right)$

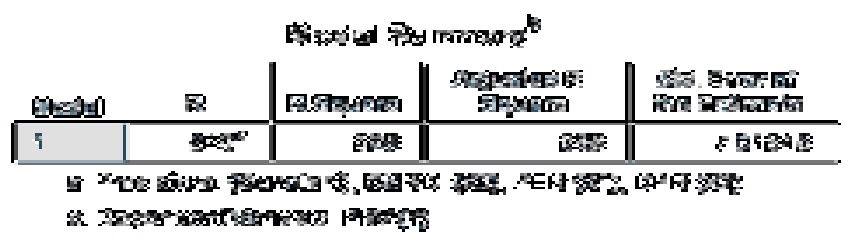

Sumber: Hasil olahan Peneliti dengan SPSS 25.0

Besarnya $\mathrm{R}^{2}$ berdasarkan hasil analisis dengan menggunakan SPSS 25.0 diperoleh sebesar 89,8\%. Dengan demikian besarnya pengaruh yang diberikan oleh variabel Keputusan Investasi $\left(\mathrm{X}_{1}\right)$, Kebijakan Dividen $\left(\mathrm{X}_{2}\right)$, dan Pengungkapan Laporan Berkelanjutan $\left(\mathrm{X}_{3}\right)$ terhadap Nilai Perusahaan $(\mathrm{Y})$ adalah sebesar $89,8 \%$ sedangkan sisanya sebesar 10,2\% dipengaruhi oleh faktor lain yang tidak diteliti dalam penelitian ini.

\section{DISKUSI}

\section{Pengaruh Keputusan Investasi terhadap Nilai Perusahaan}

Berdasarkan uji parsial tabel uji t dapat dilihat bahwa Keputusan Investasi (PER) memiliki nilai $\mathrm{t}$ hitung $>\mathrm{t}$ tabel $(14,499>2,03951)$ dengan tingkat signifikansi sebesar 0.000 maka keputusan adalah $\mathrm{Ha}_{1}$ diterima dan $\mathrm{Ho}_{1}$ ditolak. Hal ini dapat diinterpretasikan bahwa terdapat pengaruh positif antara Keputusan Investasi (PER) terhadap Nilai Perusahaan (PBV). Jadi, semakin tinggi nilai Keputusan Investasi akan mempengaruhi Nilai Perusahaan. Artinya, dengan menghasilkan rasio Price Earning Ratio (PER) yang semakin tinggi maka hal ini dapat menunjukkan bahwa semakin tinggi pula nilai perusahaan. PER yang tinggi didapatkan dari harga saham penutupan dengan laba bersih perlembar saham. Jika perusahaan mendapatkan laba yang tinggi maka harga sahampun akan meningkat, sehingga berpengaruh terhadap nilai perusahaan yang ikut meningkat.

Hasil penelitian sejalan dengan penelitian yang telah dilakukan oleh Muharti dan Anita (2017) menunjukkan bahwa keputusan investasi berpengaruh positif terhadap nilai perusahaan dalam 
hal ini menunjukkan langsung terdapat hubungan antara keputusan investasi dengan nilai perusahaan. Keputusan investasi sangat penting untuk meningkatkan nilai perusahaan karena jenis investasi ini memberikan sinyal tentang pertumbuhan pendapatan perusahaan yang diharapkan di masa yang akan datang dan mampu meningkatkan nilai pasar perusahaan (Sugiarto \& Santosa, 2018). Jika perusahaan salah dalam pemilihan investasi, maka akan mengganggu kelangsungan hidup perusahaan dan meningkatkan nilai perusahaan, sehingga manajer harus menjaga perkembangan investasi perusahaan.

\section{Pengaruh Kebijakan Dividen terhadap Nilai Perusahaan}

Berdasarkan uji parsial tabel uji t dapat dilihat bahwa Kebijakan Dividen (DPR) memiliki nilai $\mathrm{t}$ hitung $>\mathrm{t}$ tabel $(3,412>2,03951)$ dengan tingkat signifikansi sebesar 0.001 maka keputusan adalah $\mathrm{Ha}_{2}$ diterima dan $\mathrm{HO}_{2}$ ditolak. Hal ini dapat diinterprestasikan bahwa terdapat pengaruh positif antara Kebijakan Dividen (DPR) terhadap Nilai Perusahaan (PBV). Jadi semakin tinggi Kebijakan Dividen akan semakin tinggi Nilai Perusahaan. Artinya, dengan mendapatkan nilai Dividend Payout Ratio (DPR) yang tinggi maka dapat ditunjukkan bahwa semakin tinggi pula nilai perusahaan. DPR yang tinggi didapatkan dari dividen tunai per lembar saham dengan laba bersih per lembar saham. Jika perusahaan mendapatkan laba yang tinggi maka dividen yang dibayarkan akan tinggi pula dengan hal ini akan meningkatkan nilai perusahaan.

Hasil penelitian ini sejalan dengan penelitian yang dilakukan oleh Syafitri dan Farida (2017) dan Santosa (2010), kebijakan dividen berpengaruh positif dan memiliki hubungan terhadap nilai perusahaan. Dapat disimpulkan bahwa berdasarkan Theory Bird In The Hand besarnya dividen yang dibagikan kepada para pemegang saham akan menjadi daya tarik bagi pemegang saham karena sebagian investor cenderung lebih menyukai dividen dibandingkan dengan Capital Gain karena dividen bersifat lebih pasti. Banyaknya investor yang berinvestasi diperusahaan dapat menyebabkan meningkatnya harga saham sehingga dengan meningkatnya harga saham akan meningkatkan nilai perusahaan itu sendiri. Maka dalam hal ini kebijakan dividen yang ditetapkan oleh perusahaan dapat mempengaruhi nilai perusahaan.

\section{Pengaruh Pengungkapan Laporan Berkelanjutan terhadap Nilai Perusahaan}

Berdasarkan uji parsial tabel uji t dapat dilihat bahwa Pengungkapan laporan berkelanjutan memiliki nilai $\mathrm{t}$ hitung $<\mathrm{t}$ tabel $(0,884<2,03951)$ dengan tingkat signifikansi sebesar 0,384 maka keputusan adalah terima $\mathrm{Ha}_{3}$ ditolak dan $\mathrm{H}_{3}$ diterima. Hal ini dapat diinterpretasikan bahwa tidak terdapat pengaruh antara pengungkapan laporan berkelanjutan terhadap nilai perusahaan. Jadi tinggi atau rendahnya nilai pengungkapan laporan berkelanjutan tidak akan mempengaruhi nilai perusahaan. Artinya, dengan mendapatkan nilai CSRDI yang semakin tinggi maka tidak akan mempengaruhi nilai perusahaan. Hal ini menyatakan bahwa semakin tinggi pengungkapan laporan berkelanjutan yang dilakukan perusahaan, maka tidak mempengaruhi nilai perusahaan. Selain itu, diakibatkan oleh kecenderungan investor dalam membeli saham tanpa memerhatikan perusahaan tersebut mengungkapkan program Corporate Social Responsibility (CSR) atau pun tidak, sehingga kurangnya perhatian dari para investor dan mengakibatkan rendahnya pengungkapan laporan berkelanjutan. Selain itu, peraturan pemerintah dalam pengungkapan laporan berkelanjutan masih bersifat voluntary, yang mana pemerintah belum mengharuskan kepada perusahaan untuk memberikan persentase dana untuk melakukan program Corporate Social Responsibility (CSR), sehingga jumlah perusahaan yang menerbitkan laporan berkelanjutan masih tergolong rendah.

Penelitian ini sejalan yang dilakukan oleh Tiarawati (2015) bahwa rendahnya tingkat pengungkapan CSR yang dilakukan oleh perusahaan dikarenakan kurangnya kesadaran dari pihak manajemen terhadap pembangunan ekonomi berkelanjutan. Sedangkan, tingginya pengungkapan 
Corporate Social Responsibility (CSR) yang dilakukan perusahaan tidak akan mempengaruhi penilaian para investor tentang kinerja perusahaan karena investor lebih suka melihat kinerja perusahaan pada rasio keuangannya. Hal ini kemungkinan terjadi dikarenakan kualitas pengungkapan laporan berkelanjutan yang masih rendah yang mana perusahaan masih mementingkan kepentingan perusahaan daripada kepentingan lingkungan dan sosial sehingga kurangnya pengungkapan Corporate Social Responsibility (CSR) pada laporan berkelanjutan yang disebut sebagai sustainability report.

\section{SIMPULAN}

Berdasarkan analisis dan pembahasan di atas maka dapat disimpulkan sebagai berikut:

1. Hasil uji parsial (uji t) memberikan hasil bahwa:

a. Variabel keputusan investasi berpengaruh positif terhadap nilai perusahaan.

b. Variabel kebijakan dividen berpengaruh positif terhadap nilai perusahaan.

c. Variabel pengungkapan laporan berkelanjutan tidak berpengaruh terhadap nilai perusahaan.

2. Hasil uji simultan (uji F) memberikan hasil bahwa seluruh variabel independen yang meliputi keputusan investasi, kebijakan dividen, dan pengungkapan laporan berkelanjutan secara simultan berpengaruh terhadap nilai perusahaan.

\section{Saran}

Dalam penelitian selanjutnya disarankan dapat menambah tahun penelitian sehingga jumlah sampel perusahaan yang akan diteliti akan semakin banyak. Bagi penelitian selanjutnya diharapkan dapat menambah atau mengubah variabel independen seperti Keputusan Pendanaan, Good Corporate Governance (GCG), Kepemilikan Manajerial, Profitabilitas dan Leverage karena dimungkinkan variabel lain yang tidak dimasukkan dalam penelitian ini berpengaruh terhadap Nilai Perusahaan. Bagi penelitian selanjutnya diharapkan dapat mengubah proksi atau pengukuran yang lain.

\section{Ucapan Terima Kasih}

Penelitian ini dapat dilaksanakan dengan baik berkat bantuan dari berbagai pihak, untuk itu Team Peneliti mengucapkan terima kasih kepada Universitas YARSI, Dosen dan Staf Fakultas Ekonomi dan Bisnis Universitas YARSI, dan semua pihak yang telah membantu serta memberikan kritik dan saran dalam penelitian ini.

\section{REFERENSI}

Ambarwati Sri Dewi Ari. 2010. Manajemen Keuangan Lanjut. Edisi Pertama, Cetakan Pertama. Yogyakarta: Graha Ilmu.

Aswath, Damodaran. 2001. Keuangan Perusahaan: Teori dan Praktik. Edisi Internasional. Willey: New York.

Brigham, E. F., \& Houston, J. F. (2016). Fundamentals of Financial Management: Concine, Ninth Edition. In Light-Emitting Diodes. https://doi.org/10.1017/CBO9780511790546.026

Elkington, Jhon. 2004. Kanibal Dengan Garpu: Garis Tiga Bawah di Bisnis Abad 21. Oxford. UK: Capstone.

Fardiana, Elvia Astri. 2018. "Pengaruh Kebijakan Deviden, Corporate Social Responsibility, Ukuran Perusahaan dan Struktur Modal terhadap Nilai Perusahaan pada Perusahaan Manufaktur". Skripsi. Surabaya: STIE Perbanas.

Fauziah, Eti Malik. 2019. "Pengaruh Ukuran Perusahaan, Profitabilitas, Keputusan Investasi dan Keputusan Pendanaan Terhadap Nilai Perusahaan Dengan Kebijakan Dividen Sebagai 
Variabel Interventing Serta Tinjauan Dari Sudut Pandang Islam". Skripsi. Jakarta: Universitas YARSI.

Febriawan, M., \& Santosa, P. W. (2018). Return Saham dan Faktor Fundamental pada Pra Krisis Ekonomi Global 2008 di Bursa Efek Indonesia. Journal Ekonomi Dan Bisnis, 2(2), 232-248.

Ghozali, Imam. 2018. Aplikasi Analisis Multivariate Dengan program IBM SPSS 25. Universitas Diponegoro: Semarang.

Gumanti, Tatang Ary. 2013. Kebijakan Dividen: Teori, Empiris, dan Implikasi. Edisi 1. Yogyakarta: UPP STIM YKPN.

Harmono. 2009. Manajemen Keuangan Berbasis Balanced Scorecard (Pendekatan Teori, Kasus, dan Riset Bisnis). Jakarta: Bumi Aksara.

Muharti, dan Rizqa Anita. 2017. "Pengaruh Keputusan Investasi, Pendanaan, Kebijakan Deviden Terhadap Nilai Perusahaan (Studi Pada Perusahaan Sektor Property dan Real Estate Di Bursa Efek Indonesia Periode 2011-2014)". Jurnal Ilmiah Ekonomi dan Bisnis. Vol 14(2).

Nurfina, Hida Efri. 2016. "Pengaruh Pengungkapan Corporate Social Responsibility, Kebijakan Dividen, Profitabilitas, Struktur Modal, dan Ukuran Perusahaan terhadap Nilai Perusahaan (Studi pada Perusahaan Manufaktur yang Terdaftar di Bursa Efek Indonesia Periode 2010-2014". Skripsi. Semarang: Universitas Diponegoro.

Nursania, Indah. 2019. "Pengaruh Faktor Internal Perusahaan Terhadap Nilai Perusahaan dan Tinjauannya Dari Sudut Pandang Islam”. Skripsi. (Studi Pada Perusahaan Manufaktur Sektor Food and Beverage Yang Terdaftar di Bursa Efek Indonesia Tahun 2012-2017)”. Skripsi. Jakarta: Universitas YARSI.

Santosa, P. W., \& Hidayat, A. (2014). Riset Terapan: Teori dan Aplikasi (First Edit). Globalstat Solusi Utama.

Santosa, P. W. (2010). Longterm Performance Trends Analysis and Managing Expectation for Active Value (Case Study PT Indocement Tunggal Prakarsa, Tbk). Finance \& Accounting Journal, 12(02), 94-101. https://doi.org/10.9744/jak.12.2.pp.94-101

Santosa, P. W. (2019). Financial Performance, Exchange Rate and Stock Return: Evidence from Manufacturing Sector. Jurnal Manajemen Teknologi, 18(3), 205-217. https://doi.org/10.12695/jmt.2019.18.3.5

Sartono, Agus. 2010. Manajemen Kenangan Teori dan Aplikasi. Yogyakarta: BPFE.

Sudana, I made. 2015. Manajemen Keuangan Perusahaan Teori dan Praktek. Jakarta: Erlangga.

Sugiarto, M., \& Santosa, P. W. (2018). Pengaruh Indikator Makroekonomi, Kinerja Keuangan, dan

Tata Kelola Terhadap Nilai Perusahaan Pada Sektor Properti di Bursa Efek Indonesia. Journal of Economics and Business Aseanomics, 2(2), 288-312.

Syafitri, Ihdina dan Lena Farida. 2017. "Pengaruh Keputusan Pendanaa dan Kebijakan Dividen Terhadap Nilai Perusahaan pada Perushaan Property dan Real Estate yang Terdaftar di BEI Tahun 2010-2014". Jurnal FISIP. Vol 4(2).

Tandelilin, Eduardus. 2010. Portofolio dan Investasi Teori dan Aplikasi. Edisi pertama. Yogyakarta: Kanisius.

Tiarawati, Ayu. 2015. "Pengaruh Keputusan Investasi, Keputusan Pendanaan, Kebijakan Deviden dan Pengungkapan Corporate Social Responsibility terhadap Nilai Perusahaan. Skripsi. Surakarta: Universitas Muhammadiyah Surakarta.

Umam, Aridho Choirul, dan Ulil Hartono. 2019. "Pengaruh Ukuran Perusahaan, Profitabilitas, Struktur Modal, Kebijakan Dividen, GCG dan CSR Terhadap Nilai Perusahaan (Studi 
pada Perusahaan Sektor Finance di Bursa Efek Indonesia)". Jurnal Ilmu Manajemen. Vol. 7(3).

Untung, Budi. 2014. CSR Dalam Dunia Bisnis.Yogyakarta: CV Andi Offset. 